\title{
Creating Competitive Advantage for Vietnamese Manufacturing and Service Firms: The Role of Collaborative Culture and Innovation Capability
}

\author{
Do Khoi Nguyen ${ }^{1}$, Le Ba Phong ${ }^{1,2}$ \& Lei Hui ${ }^{1}$ \\ ${ }^{1}$ School of Business Administration, Hunan University, Changsha, China \\ ${ }^{2}$ Faculty of Business Management, Hanoi University of Industry, BacTuLiem, Hanoi, Vietnam \\ Correspondence: Lei Hui, School of Business Administration, Hunan University, Changsha, Hunan, China.
}

Received: January 17, 2019

Accepted: February 7, $2019 \quad$ Online Published: February 14, 2019

doi:10.5430/ijba.v10n2p32

URL: https://doi.org/10.5430/ijba.v10n2p32

\begin{abstract}
Collaborative culture and innovation are broadly recognized as the crucial antecedents of creating competitive advantage for firms. However, the research on how collaborative culture connects with innovation to enhance firm's competitive advantage is still sparse and limited. To clarify these relations, this study uses structural equations modeling (SEM) based on data collected from 265 manufacturing and service firms in Vietnam to explore the correlation between collaborative culture, innovation and competitive advantage. The result indicates that collaborative culture has significant effects on both innovation capability and competitive advantage. In addition, innovation capability acts as the mediator between collaborative culture and competitive advantage. The findings of this study provide useful guidelines for both scholars and practitioners in identifying the effective way to increase competitive advantage for firms.
\end{abstract}

Keywords: collaborative culture, innovation capability, competitive advantage, SEM

\section{Introduction}

Before the changing rapid and difficult to predict of business environment, improving innovation capability is considered as one of the most optimal solutions for firms to create competitive advantage and improving organizational performance in long term (Le \& Lei, 2018; Yang et al., 2018; Le \& Lei, 2019). Innovation brings firms a competitive advantage in many aspects such as: market performance, market share maintenance, production shortening, and accelerating new products development (Tidd et al., 2006), operational efficiency and service quality (Hsueh \& Tu, 2004; Parasuraman, 2010), meeting customer's needs, developing new capabilities, performance or superior profitability (Calantone et al., 2002; Sadikoglu \& Zehir, 2010) in comparison with those of the competitors. As a result, scholars and practitioners are looking for new and effective paths to improve firm's innovation capability for attaining and sustaining competitive advantage (Hogan \& Coote, 2014; Yang et al., 2018). Previous studies pointed out that organizational culture has significant role in creating the openness, collaborative climate and trust which are the root of fostering employees sharing more ideas and knowledge for innovation and competitive advantage (Donate \& Guadamillas, 2011; Lei et al., 2017; Yang et al., 2018). However, the research on the relationship between collaborative culture (CC) which is seen as the core values of organizational culture, innovation and competitive advantage is still limited (Lei et al., 2017; Yang et al., 2018). Thus, to provide more understanding on these relations, this paper will investigate the relationship between $\mathrm{CC}$, innovation and competitive advantage in case of Vietnamese firms. The research issue is new, significant and necessary by following reasons.

First, how to improve firm's innovation capability is the hot topic of scholars and practitioners (Breznik \& Hisrich, 2014; Leavy, 2015; Yang et al., 2018). To improve firm's innovation, Anderson et al. (2014) emphasized the necessity of identifying the antecedents of innovation by posing a question that: "What is the relationship between organizational resources and different types of organizational innovation?" Meanwhile, organizational culture and CC are viewed as the crucial organizational resources (Wang \& Noe, 2010). Therefore, exploring how CC related to innovation capability is very necessary. So, the first research question arises: RQ1. Does CC have positive impact on innovation capability?

Second, although some recent works showed that $\mathrm{CC}$ has positive impacts on both innovation (Yang et al., 2018) and 
competitive advantage (Lei et al., 2017). However, Lopez et al., (2004) supposed that CC do not constitute in itself a source of competitive advantage. Moreover, the role of organizational culture's values towards innovation is not clear by it could enhance or inhibit creativity and innovation (Glor, 1997; Tushman \& O'Reilly, 1997). To clarify the correlation between CC and competitive advantage, the second research question needs to be addressed: RQ2. Does CC have positive impact on competitive advantage?

Finally, previous studies show the potential mediating role of innovation between CC and competitive advantage by indicating that CC is the sources of successful innovation (Barczak et al., 2010; Kucharska \& Kowalczyk, 2016; Yang et al., 2018), which, in turn, has positive impacts on firm's competitive advantage (Lei et al., 2018; Le \& Lei; 2018). However, the empirical research on the mediating role of innovation between CC and competitive advantage is still deficient and restricted. Consequently, the third research question needs to be answered: RQ3. Does innovation capability mediate between CC and competitive advantage?

To answer the above research questions, this study used structural equations modeling (SEM) to test the correlation between the constructs based on a survey of 265 directors/managers from 265 firms in some developed provinces of Vietnam. Our research is expected to provide both theoretical initiatives and practical implication on organizational culture, innovation, and firm's competitive advantage.

\section{Literature Review and Hypotheses Development}

\subsection{Collaborative Culture and Innovation Capability}

Organizational culture that widely regarded as the key organizational resource has attracted the attention of many scholars for several decades (e.g., Schein. 1985; David \& Fahey, 2000; López et al., 2004; Xiaoming \& Junchen, 2012; Lei et al., 2017). Culture is typically defined as a model of basic assumption, values and beliefs, which are shared by members in organizations and providing norms of expected behaviors that employees might follow (Schein, 1992; Miron et al., 2004). These shared values constitute the foundation of communication and mutual understanding. Thereby it has impacts on employee behavior through its two main functions: internal integration and coordination (Hofstede, 1988; Martins \& Terblanche, 2003). By reviewing literature, we have found that organizational culture has significant impacts on the organization's strategic outcomes. The current literature supports for significant and important role of organizational in creating a positive climate for firm to change and increase firm's innovation capability (Nacinovic et al., 2009; Škerlavaj et al., 2010) which refers to the adoption of a new idea or behavior relating to a system, policy, program, device, process, product or service (Hage, 1999). However, it seems to have a little paradox in the sense that specific aspects of organizational culture can enhance or inhibit creativity and innovation (Glor, 1997; Tushman and O'Reilly, 1997). To explore deeper the influences of specific values of organizational culture on innovation, our study will focus on examining the effects of collaborative culture-core values of organizational culture on firm's innovation capability.

Collaborative culture is characterized by long-term vision and advance management of the change, team-work, communication, risk assumption, respect and empowerment, and promoting the knowledge of individuals (Lopez et al., 2004; Yang et al., 2018). Basically collaborative culture is built based on the mutual respect, care and support each other (Bstieler \& Hemmert, 2010; Lei et al., 2017). Collaborative culture is the origin of creating collective strength because it can mobilize the involvement of all members for common goals. Consequently it will greatly enhance the ability of organizations to innovate.

Many previous studies indicated the important role of values of organizational culture in innovation (Ahmed, 1998; Dobni, 2008; Higgins \& Mcallaster, 2002; Jamrog et al., 2006; Lau \& Ngo, 2004; Martins \& Terblanche, 2003; Mumford, 2000). The main reason is that culture can stimulate innovation behavior among the members of an organization because it results in accepting innovation between members as a basic value of the organization and fosters commitment to innovation (Hartmann, 2006). Martin and Terblanche (2003) proved that behaviors and communications encouraging innovation in an organization included: mistake handing, idea generating, continuous learning culture, risk taking, competitiveness, support for change, conflict handling, open communication. DeCusatis (2008) also affirmed that collaboration itself had been found to lead to innovative and creative outcomes. More recently, Yang et al. (2018) indicated that collaborative culture has significant impacts on both product and process innovation in case of Chinese firms.

Above arguments supports the collaborative culture's positive effect on innovation capability, so the following hypothesis is posed:

H1: Collaborative culture has a positive impact on innovation capability 


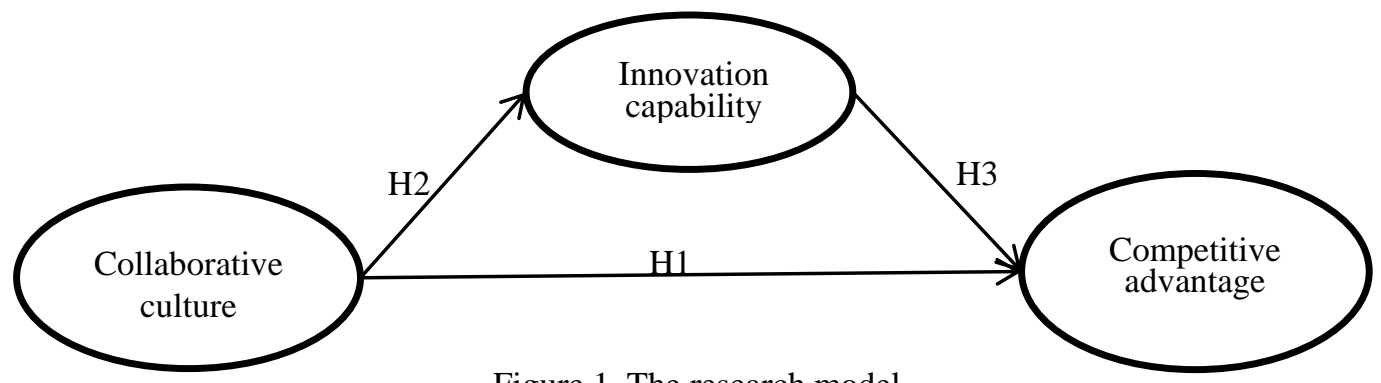

Figure 1. The research model

\subsection{Collaborative Culture and Competitive Advantage}

Prior researches have shown the positive relationship between organizational culture and competitive advantage. O'Reilly and Chatman (1996) proposed that the "strong cultures" was a series of norms and values which were shaped and widely shared throughout the entire organization and related to the high performance of a wide range of industries (Deal \& Kennedy, 1982; Denison, 1990; Peters \& Waterman, 1982) and one of the important reasons was that "strong cultures" improved organizational performance by facilitating internal behavioral consistency (Sørensen, 2002). Organizational culture is considered as a resource which directly or indirectly brings competitive advantages and organizational success (Rouse \& Daellenbach, 1999). Organizational culture has been employed as an independent and suitable competition factor, especially at hyper-dynamic markets as was in the case of Hewlett-Packard, Nissan, Zappos (Kotter \& Heskett, 1992).

In addition, resource-based view reported that firms will create competitive advantage based on having high operation efficiency and getting profits above the average if their resources and capabilities are valuable, scarce, inimitable and non-replaceable (Barney, 1991; Grant, 1991; Wu, 2010). Barney (1991) noted that, because resources were diversely distributed among firms, so only a firm's unique resources might lead to persistently superior performance and achieving competitive advantage. From a resource-based point of view, we've found that collaborative culture can be a kind of core competence and provide firms with competitive advantage because it is valuable, rare, inimitable and difficult to replace. Collaborative culture is valuable because it is an effective platform for progress within the organization (Carter, 1999; Wagner, 1998; Weiss, 1999). More specifically, collaborative culture is a valuable competence in creating better communications, stimulating information sharing and making greater co-operations (Calton \& Lad, 1995; Larson \& LaFasto, 1989; Littler et al., 1995; Strutton et al., 1993; Whitener et al., 1998), as an apparent result, it leads to greater creative efforts. Collaborative culture is also very difficult for competitors to imitate and to transfer because one of the most important characteristics of culture is tacit, intangible and with high complexity (Coyne, 1986). Simultaneously, because firms try to reduce organizational conflict and to work effectively across borders, the need to assess and to merge diverse, complementary skills that exist in different functions and across different organizations (Raghunathan, 1999; Sanders, 2007; Wang \& Wei, 2007). With these realities, the scholars suggested that collaboration act as a valued dynamic capability (Agarwal \& Selen, 2009; Ettlie \& Pavlou, 2006); it makes a collaborative culture becoming a special resource and very difficult to replace. Similarly, collaborative culture is also rare because it is very difficult for firms to have a successful collaborative culture.

In sum, above arguments showed that collaborative culture is an organization's type of core resource, which is the root of creating competitive advantages. Furthermore Lei et al. (2017) reported that collaborative culture is significant related to firm's sustainable competitive advantage. Therefore, this study proposes the following hypothesis (see Fig.1):

H2: Collaborative culture is significant associated with firm's competitive advantage.

\subsection{Innovation Capability and Competitive Advantage}

Innovation capability has been recognized as an important factor for firms to create value and to have a great influence on competition (Mintzberg, 1994). Innovation can be a source of competitive advantage (Hinterhuber \& Liozu, 2014). Innovation helps firms adapt well with the uncertainty of the external environment and become one of the most important factors leading to the success of the business in the long term, particularly in the dynamic markets (Vrakking, 1990; Balkin et al., 2000; Baker \& Sinkula, 2002). According to Wang and Wang (2012), innovation capability allows firms to make full use of existing resources to improve efficiency and potential value, and to bring 
new intangible assets into organization. Innovation capability helps firms to attain a competitive advantage in several aspects: market performance, market share maintenance, production shortening and accelerating new products development (Tidd et al., 2006); operational efficiency and service quality (Hsueh \& Tu, 2004; Parasuraman, 2010). Success in technology innovation enables firms to create and to maintain a competitive advantage (Martin-de Castro et al., 2013).

Overall, the positive relationship between innovation capability and competitive advantage is supported. To provide more evidence for this relationship, this study proposes the hypothesis as following (see Fig.1):

H3: Innovation capability significantly impacts on competitive advantage.

\section{Research Methodology}

\subsection{Samples and Data Collection}

This study employs survey method for data collection. We use the measurement items, which are adapted from exiting scales in the literature for developing an initial list of items. After that, for revising the measurement items to align with Vietnam context, we carry out pilot tested before the process of formal data collection, in which, pretest by means of in-depth interviews with five outstanding academic scholars who have profound knowledge in strategic management in three universities, and six directors/managers from six different firms. Pilot test was conducted with 30 firms to determine the efficiency of the questionnaire. This study examined a sample of 265 firms in some of the most developed cities of Vietnam such as Hanoi, Haiphong and Hochiminh. We assessed non-response by following the method proposed by Armstrong and Overton (1977). t-test is used to compare the earlier 75 respondents and the last 75 respondents. The results showed no significant differences in the mean responses for all the variables measured in the questionnaire $(p>0.05)$.

\subsection{Measures}

All the items are measured via five-point Likert-type scales, ranging from "1" (strongly disagree) to "5" (strongly agree). The Appendix A, B and C present these scales in full detail. Collaborative culture is measured by eight items reflecting firm value which are traditionally attributed to collaborative culture: vision and prediction about changes in the long term, encouragement of dialogue between members in the firm, trust and respect of the personal views, teamwork, empowerment, ambiguity tolerance, risk assumption and encouragement for diversity. These scales derived from the research of Yang et al. (2018). To measure innovation capability, we used six scales derived from the study of Lin (2007) to reflect firm's capabilities of creating new products, services and processes. Finally, to measure competitive advantage, this study use four items derived from the study of Su et al., (2009) to reflect firm's ability in occupying some position and attaining the sustainable benefits from the successful strategy where the competitors cannot copy its successful strategy.

\section{Result}

\subsection{Measurement Testing}

We firstly carried out an exploratory factor analysis (EFA) to eliminate factors had factor loading lower than 0.5 to ensure the practicality of the research (Hair at al., 1998). We then performed confirmatory factor analysis (CFA) to evaluate the overall measurement model to evaluate the validity of measurement model. We accessed convergent validity by considering factor loading (which should exceed 0.5 ); composite reliabilities (CR) (which should exceed 0.6 ); and the average variance extracted (AVE) (which should be greater than 0.5 for all constructs (Fornell \& Larcker, 1981). Besides, the internal reliability of scales are well if Crombach's alpha $(\mathrm{C} \alpha)$ is higher than 0.7 (Nunnly \& Bernstein, 1994). Table 1 shows that the research model met the convergent validity criteria. 
Table 1. Results of CFA and internal reliable testing

\begin{tabular}{|c|c|c|c|c|c|c|c|}
\hline Construct & Mean & SD & Item & Loading & AVE & $\mathrm{CR}$ & $\mathrm{C} \alpha$ \\
\hline \multirow[t]{8}{*}{ Collaborative culture (CC) } & 3.50 & 0.43 & $\mathrm{CC} 1$ & $0.64 * * *$ & 0.55 & 0.91 & 0.91 \\
\hline & & & $\mathrm{CC} 2$ & $0.76 * * *$ & & & \\
\hline & & & $\mathrm{CC} 3$ & $0.64 * * *$ & & & \\
\hline & & & $\mathrm{CC} 4$ & $0.73 * * *$ & & & \\
\hline & & & CC5 & $0.65^{* * *}$ & & & \\
\hline & & & CC6 & $0.82 * * *$ & & & \\
\hline & & & CC7 & $0.69 * * *$ & & & \\
\hline & & & $\mathrm{CC} 8$ & $0.82 * * *$ & & & \\
\hline \multirow[t]{6}{*}{ Innovation capability (IC) } & 3.69 & 0.48 & IC1 & $0.79 * * *$ & 0.59 & 0.90 & 0.90 \\
\hline & & & $\mathrm{IC} 2$ & $0.73 * * *$ & & & \\
\hline & & & IC3 & $0.78^{* * *}$ & & & \\
\hline & & & IC4 & $0.80 * * *$ & & & \\
\hline & & & IC5 & $0.71 * * *$ & & & \\
\hline & & & IC6 & $0.77 * * *$ & & & \\
\hline \multirow[t]{4}{*}{ Competitive advantage (CA) } & 3.84 & 0.51 & CA1 & $0.78^{* * *}$ & 0.66 & 0.88 & 0.88 \\
\hline & & & CA2 & $0.86^{* * *}$ & & & \\
\hline & & & CA3 & $0.86^{* * *}$ & & & \\
\hline & & & CA4 & $0.74 * * *$ & & & \\
\hline
\end{tabular}

Notes: $C \alpha \geq 0.7 ; C R \geq 0.7 ; A V E \geq 0.5 ; * * * p<0.001$.

Discriminated validity indicated that factors that are supposed to measure a specific construct do not predict conceptually unrelated criteria (Kline, 2010). According to Fornell and Larcker's (1981), to meet criteria, the square root of AVE for each construct must be higher than the square correlation between the construct and the other constructs in the model. Table 2 shows that the square root of AVE of the elements in diagonal is higher than correlations between constructs and the other construct. Therefore, the discriminated validity of the measurement in this study is acceptable.

Table 2. Descriptive statistics and construct correlations

\begin{tabular}{lccc}
\hline Construct & CC & IC & CA \\
\hline Collaborative culture (CC) & $\mathbf{0 . 7 4}$ & & \\
Innovation capability (IC) & 0.59 & $\mathbf{0 . 7 7}$ & \\
Competitive advantage (CA) & 0.61 & 0.69 & $\mathbf{0 . 8 1}$ \\
\hline
\end{tabular}

Regarding the degree fit of the research model Table 3 reports that, all fit indices meet satisfactory levels.

Table 3. Overall fit index of the CFA model

\begin{tabular}{lcl}
\hline Fit index & Scores & Recommended threshold value \\
\hline Absolute fit measures & & \\
CMIN/df & 1.732 & $\leq 2^{\mathrm{a}} ; \leq 5^{\mathrm{b}}$ \\
GFI & 0.911 & $\geq 0.90^{\mathrm{a}} ; \geq 0.80^{\mathrm{b}}$ \\
RMSEA & 0.053 & $\leq 0.8^{\mathrm{a}} ; \leq 0.10^{\mathrm{b}}$ \\
Incremental fit & & \\
measures & & \\
NFI & 0.930 & $\geq 0.90^{\mathrm{a}} ;$ \\
AGFI & 0.883 & $\geq 0.90^{\mathrm{a}} ; \geq 0.80^{\mathrm{b}}$ \\
CFI & 0.969 & $\geq 0.90^{\mathrm{a}} ;$ \\
Parsimonious fit & & \\
measures & & \\
PGFI & 0.692 & The higher the better \\
PNFI & 0.790 & The higher the better \\
\hline
\end{tabular}

a Acceptability: acceptable

b Acceptability: marginal 


\subsection{Structural Model}

This section presents the main result of the hypothesis testing of the structural relationship among the latent variables (Table 4, Table 5 and Fig.2.)

Hypothesis $\mathrm{H} 1$ refers to the positive effect of collaborative culture on competitive advantage. The results in Table 5 and Fig.2 show that the effect of collaborative culture on competitive advantage is statistically significant and quite large $(\beta=0.317 ; p<0.001)$, so it supports hypothesis $\mathrm{H} 1$.

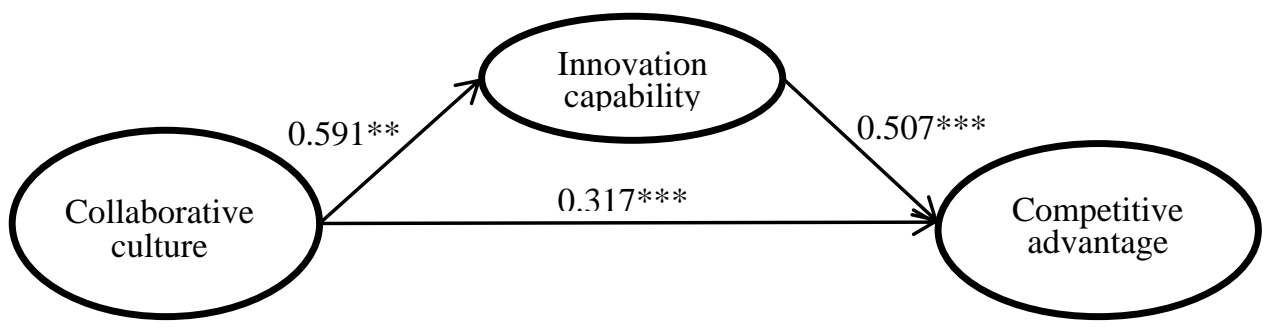

Figure 2. Path coefficients of the structural model

Table 4. Structure model results

\begin{tabular}{lcccl}
\hline Hypotheses & Proposal effect & Estimate & $\mathrm{P}$ & Results \\
\hline $\mathrm{H} 1: \mathrm{CC} \rightarrow \mathrm{CA}$ & + & $0.317^{* * *}$ & $<0.001$ & Supported \\
$\mathrm{H} 2: \mathrm{CC} \rightarrow \mathrm{IC}$ & + & $0.591^{* * *}$ & $<0.001$ & Supported \\
$\mathrm{H} 3: \mathrm{IC} \rightarrow \mathrm{CA}$ & + & $0.507^{* * *}$ & $<0.001$ & Supported \\
\hline
\end{tabular}

*** Significant at the 0,001 level

Hypothesis of $\mathrm{H} 2$ relating to the positive effect of collaborative culture on innovation capability. The results in Table 4 indicated that the effect of collaborative culture on innovation capability is also statistically significant $(\beta=0.591$; $p<0.001$ ) supported hypothesis $\mathrm{H} 2$.

Hypothesis of $\mathrm{H} 3$ relating to the positive effect of innovation capability on competitive advantage. The results in Table 4 indicated that innovation capability's influence on competitive advantage is statistically significant $(\beta=$ $0.507 ; p<0.001)$. Hypothesis $\mathrm{H} 3$ is, therefore, also supported.

In addition, we performed the bootstrap confidence intervals method with 3,000 iterations to test the significance of indirect effects to show the evidence about the mediating role of innovation capability; direct and indirect effects, as well as total effects, are computed and listed in table 5. Table 5 firstly confirms that innovation capability acts as mediator between collaborative culture and competitive advantage.

Table 5. Direct, indirect and total effects analysis

\begin{tabular}{cccccc}
\hline \multirow{2}{*}{ Path } & \multirow{2}{*}{$\begin{array}{c}\text { Direct } \\
\text { effects }\end{array}$} & \multirow{2}{*}{$\begin{array}{c}\text { Indirect } \\
\text { effects }\end{array}$} & \multirow{2}{*}{$\begin{array}{c}\text { Total } \\
\text { effects }\end{array}$} & & \multicolumn{2}{c}{ Bias-corrected confidence intervals } \\
\cline { 5 - 6 } & & & $\begin{array}{c}\text { Lower } \\
\text { confidence level }\end{array}$ & $\begin{array}{c}\text { Upper } \\
\text { confidence level }\end{array}$ \\
\hline $\mathrm{CC} \rightarrow$ IC $\rightarrow$ CA & $0.317^{* * * *}$ & $0.300^{* * *}$ & $0.617^{* * *}$ & 0.207 & 0.432 \\
\hline
\end{tabular}

*** Significant at the 0,001 level

\section{Discussions, Implications and Conclusions}

This study contributes to the literature in following ways. First of all, many scholars proposed that organizational culture in firms have relationships not only with innovation but also with competitive advantages, and innovation have relationships with competitive advantages. However, up to now research links collaborative culture, innovation and competitive advantage in a model holistically is still lacking. So, this study contributes to fill this theoretical gap by proposing the research model to investigate the effects of collaborative culture on innovation, which, in turn, leads 
to firm's competitive advantages in a model. Secondly, for the question whether organizational culture can enhance or inhibit creativity and innovation (Glor, 1997; Tushman \& O'Reilly, 1997), the finding provides the evidence that collaborative culture with the core values of organizational culture has positive impacts on innovation capability. Thirdly, contrary to the López et al.'s (2004) findings of not supporting for the direct effect of collaborative culture on competitive advantage in the industrial and service sector of Spain, this result shows the empirical evidence that collaborative culture will create in itself a source of competitive advantage for both manufacturing and service firms in Vietnam. Finally, by investigating the mediating role of innovation capability between collaborative culture and competitive advantage, the study provides the evidence that collaborative culture directly or indirectly influence on competitive advantages through the mediating role of innovation capability.

Besides the significant contributions to the literature, this study also has some limitations. First, it only covered the definition, dimensions and consequences of collaborative culture in general. Further researches should explore more deeply by dividing collaborative culture into internal and external collaborative culture. Future research should also explore deeper the correlation between the constructs in the proposal research model by accessing three levels of collaboration including level of business unit, level of immediate superior, and level of co-workers in a workgroup (Sveiby \& Simons 2002; Tschannen-Moran, 2001). Second, this study uses cross-sectional data, therefore it may appear ability that causal relationships may change or even not reflect the positive relationship among constructs. For this reason, a longitudinal study is necessary to help overcome this limitation and consolidate the result. Third, this study did not consider the role of moderating or control variables when investigating the relationship between the latent variables. As a result, future researches may provide more useful understanding by exploring deeper the relationship between latent variables in the research model by adding moderator or control variables such as, firm size, firm age and type of service industry.

Nevertheless, this study has provided empirical evidence to prove the hypothesis that both collaborative culture and innovation significant contribute to firm's competitive advantage. The findings highlight the important role of building and promoting a collaborative climate to enhance firms' innovation capability which serves as mediator between collaborative culture and competitive advantage.

\section{References}

Agarwal, R., \& Selen, W. (2009). Dynamic capability building in service value networks for achieving service innovation. Decision Sciences, 40(3), 431-475. https://doi.org/10.1111/j.1540-5915.2009.00236.x

Ahmed, P.K. (1998). Culture and climate for innovation. European Journal of Innovation Management, 1(1), 30-43. https://doi.org/10.1108/14601069810199131

Baker, W.E., \& Sinkula, J.M. (2002). Market orientation, learning orientation and product innovation: delving into the organization's black box. Journal of Market-Focused Management, 5(1), 5-23. https://doi.org/10.1023/A:1012543911149

Balkin, D.B., Markman, G.D., \& Gomez-Mejia, L.R. (2000). Is CEO pay in high-technology firms related to innovation?. Academy of Management Journal, 43(6), 1118-1129. https://doi.org/10.5465/1556340

Barczak, G., Lassk, F., \& Mulki, J. (2010). Antecedents of team creativity: An examination of team emotional intelligence, team trust and collaborative culture. Creativity and Innovation Management, 19(4), 332-345. https://doi.org/10.1111/j.1467-8691.2010.00574.x

Barney, J. (1991). Firm resources and sustained competitive advantage. Journal of Management, 17(1), 99-120. https://doi.org/10.1177/014920639101700108

Breznik, L., \& D. Hisrich, R. (2014). Dynamic capabilities vs. innovation capability: are they related?. Journal of Small Business and Enterprise Development, 21(3), 368-384. https://doi.org/10.1108/JSBED-02-2014-0018

Bstieler, L., \& Hemmert, M. (2010). Increasing Learning and Time Efficiency in Interorganizational New Product Development Teams. Journal of Product Innovation Management, 27(4), 485-499. https://doi.org/10.1111/j.1540-5885.2010.00731.x

Calantone, R.J., Cavusgil, S.T., \& Zhao, Y. (2002). Learning orientation, firm innovation capability, and firm $\begin{array}{lllll}\text { performance. Industrial } & \text { Marketing }\end{array}$ https://doi.org/10.1016/S0019-8501(01)00203-6

Calton, J.M., \& Lad, L.J. (1995). Social contracting as a trust-building process of network governance. Business Ethics Quarterly, 5(2), 271-295. https://doi.org/10.2307/3857357 
Carter, M. (1999). Energizing our workforce. Child Care Information Exchange, 76-81.

Coyne, K.P. (1986). Sustainable competitive advantage-What it is, what it isn't. Business Horizons, 29(1), 54-61. https://doi.org/10.1016/0007-6813(86)90087-X

David, W., \& Fahey, L. (2000). Diagnosing cultural barriers to knowledge management. The Academy of Management Executive, 14(4), 113-127.

Deal, T.E., \& Kennedy, A.A. (1982). Corporate cultures: The rites and rituals of organizational life. Reading/T. Deal, A. Kennedy-Mass: Addison-Wesley, 2, 98-103.

DeCusatis, C. (2008). Creating, growing and sustaining efficient innovation teams. Creativity and Innovation Management, 17(2), 155-164. https://doi.org/10.1111/j.1467-8691.2008.00478.x

Denison, D.R. (1990). Corporate culture and organizational effectiveness. John Wiley \& Sons.

Dobni, C.B. (2008). Measuring innovation culture in organizations: The development of a generalized innovation culture construct using exploratory factor analysis. European Journal of Innovation Management, 11(4), 539-559. https://doi.org/10.1108/14601060810911156

Donate, M.J., \& Guadamillas, F. (2011). Organizational factors to support knowledge management and innovation. Journal of Knowledge Management, 15(6), 890-914. https://doi.org/10.1108/13673271111179271

Ettlie, J.E., \& Pavlou, P.A. (2006). Technology-Based New Product Development Partnerships. Decision Sciences, 37(2), 117-147. https://doi.org/10.1111/j.1540-5915.2006.00119.x

Fornell, C., \& Larcker, D.F. (1981). Evaluating structural equation models with unobservable variables and measurement error. Journal of Marketing Research, 18(1), 39-50. https://doi.org/10.1177/002224378101800104

Glor, E. (1997). Encouraging public sector innovation. Optimum, 27(2), 41-48.

Grant, R.M. (1991). The resource-based theory of competitive advantage: implications for strategy formulation. California Management Review, 33(3), 114-135. https://doi.org/10.2307/41166664

Hage, J.T. (1999). Organizational innovation and organizational change. Annual Review of Sociology, 597-622. https://doi.org/10.1146/annurev.soc.25.1.597

Hair, J.F., Anderson, R.E., Tatham, R.L., \& William, C. (1998). Multivariate data analysis: Upper Saddle River. NJ: Prentice Hall.

Hartmann, A. (2006). The role of organizational culture in motivating innovative behaviour in construction firms. Construction Innovation, 6(3), 159-172. https://doi.org/10.1108/14714170610710712

Higgins, J.M., \& Mcallaster, C. (2002). Want innovation? Then use cultural artifacts that support it. Organizational Dynamics, 31(1), 74-84. https://doi.org/10.1016/S0090-2616(02)00073-6

Hinterhuber, A., \& Liozu, S.M. (2014). Is innovation in pricing your next source of competitive advantage? Business Horizons, 57(3), 413-423. https://doi.org/10.1016/j.bushor.2014.01.002

Hofstede, G., \& Bond, M.H. (1988). The Confucius connection: From cultural roots to economic growth. Organizational Dynamics, 16(4), 5-21. https://doi.org/10.1016/0090-2616(88)90009-5

Hogan, S.J., \& Coote, L.V. (2014). Organizational culture, innovation, and performance: A test of Schein's model. Journal of Business Research, 67(8), 1609-1621. https://doi.org/10.1016/j.jbusres.2013.09.007

Hsueh, L.M., \& Tu, Y.Y. (2004). Innovation and the operational performance of newly established small and medium enterprises in Taiwan. Small Business Economics, 23(2), 99-113. https://doi.org/10.1023/B:SBEJ.0000027663.84972.ac

Jamrog, J., Vickers, M., \& Bear, D. (2006). Building and sustaining a culture that supports innovation. People and Strategy, 29(3), 9.

Kotter, J.P., \& Heskett, J.L. (1992). Organizational culture and performance. Free Press, New York, NY.

Kucharska, W., \& Kowalczyk, R. (2016). Trust, Collaborative Culture and Tacit Knowledge Sharing in Project Management-a Relationship Model.

Larson, C., \& LaFasto, F. (1989). Teamwork: what can go right, what can go wrong. Newbury Park, CA: Sage.

Lau, C.M., \& Ngo, H.Y. (2004). The HR system, organizational culture, and product innovation. International Business Review, 13(6), 685-703. https://doi.org/10.1016/j.ibusrev.2004.08.001 
Le, P.B., \& Lei, H. (2018). The effects of innovation speed and quality on differentiation and low-cost competitive advantage: The case of Chinese firms. Chinese Management Studies, 12(2), 305-322. https://doi.org/10.1108/CMS-10-2016-0195

Le, P.B., \& Lei, H. (2019). Determinants of innovation capability: the roles of transformational leadership, knowledge sharing and perceived organizational support. Journal of Knowledge Management (In press). https://doi.org/10.1108/JKM-09-2018-0568

Leavy, B. (2015). Continuous innovation: unleashing and harnessing the creative energies of a willing and able community. Strategy \& Leadership, 43(5), 24-31. https://doi.org/10.1108/SL-06-2015-0051

Lei, H., Le, P. B., \& Nguyen, H.T.H. (2017). How Collaborative Culture Supports for Competitive Advantage: The Mediating Role of Organizational Learning. International Journal of Business Administration, 8(2), 73-85. https://doi.org/10.5430/ijba.v8n2p73

Littler, D., Leverick, F., \& Bruce, M. (1995). Factors affecting the process of collaborative product development: a study of UK manufacturers of information and communications technology products. Journal of Product Innovation Management, 12(1), 16-32. https://doi.org/10.1016/0737-6782(94)00025-B

López, S.P., Peón, J.M.M., \& Ordás, C.J.V. (2004). Managing knowledge: the link between culture and organizational learning. Journal of Knowledge Management, 8(6), 93-104. https://doi.org/10.1108/13673270410567657

Martins, E., \& Terblanche, F. (2003). Building organisational culture that stimulates creativity and innovation. European Journal of Innovation Management, 6(1), 64-74. https://doi.org/10.1108/14601060310456337

Mintzberg, H. (1994). The rise and fall of strategic planning: Preconceiving roles for planning, plans, planners. New York.

Miron, E., Erez, M., \& Naveh, E. (2004). Do personal characteristics and cultural values that promote innovation, quality, and efficiency compete or complement each other?. Journal of Organizational Behavior, 25(2), 175-199. https://doi.org/10.1002/job.237

Mumford, M.D. (2000). Managing creative people: Strategies and tactics for innovation. Human Resource Management Review, 10(3), 313-351. https://doi.org/10.1016/S1053-4822(99)00043-1

Nacinovic, I., Galetic, L., \& Cavlek, N. (2009). Corporate culture and innovation: implications for reward systems. World Academy of Science, Engineering and Technology, 53, 397-402.

O'Reilly, C., \& Chatman, J.A. (1996). Culture as social control: Corporations, cults, and commitment. Research in Organizational Behaviour, 18, 157-200.

Parasuraman, A. (2010). Service productivity, quality and innovation: Implications for service-design practice and research. International Journal of Quality and Service Sciences, 2(3), 277-286. https://doi.org/10.1108/17566691011090026

Peters, T.J., Waterman, R.H., \& Jones, I. (1982). In search of excellence: Lessons from America's best-run companies. Management \& Leadership

Raghunathan, S. (1999). Interorganizational collaborative forecasting and replenishment systems and supply chain implications. Decision Sciences, 30(4), 1053-1071. https://doi.org/10.1111/j.1540-5915.1999.tb00918.x

Rouse, M.J., \& Daellenbach, U.S. (1999). Rethinking research methods for the resource - based perspective: isolating sources of sustainable competitive advantage. Strategic Management Journal, 20(5), 487-494. https://doi.org/10.1002/(SICI)1097-0266(199905)20:5<487::AID-SMJ26>3.0.CO;2-K

Sadikoglu, E., \& Zehir, C. (2010). Investigating the effects of innovation and employee performance on the relationship between total quality management practices and firm performance: An empirical study of Turkish firms. International Journal of Production Economics, 127(1), 13-26. https://doi.org/10.1016/j.ijpe.2010.02.013

Sanders, N.R. (2007). An empirical study of the impact of e-business technologies on organizational collaboration and performance. Journal of Operations Management, 25(6), 1332-1347. https://doi.org/10.1016/j.jom.2007.01.008

Schein, E. (1992). Organisational Culture and leadership, A dynamic view (2nd ed.). San Francisco, Jossey-Bass Inc. Publishers.

Schein, E.H. (1985). Organisational culture and leadership: A dynamic view. San Francisco. 
Škerlavaj, M., Song, J.H., \& Lee, Y. (2010). Organizational learning culture, innovative culture and innovations in South Korean firms. Expert Systems With Applications, 37(9), 6390-6403. https://doi.org/10.1016/j.eswa.2010.02.080

Strutton, D., Pelton, L.E., \& Lumpkin, J.R. (1993). The relationship between psychological climate and salesperson-sales manager trust in sales organizations. Journal of Personal Selling \& Sales Management, 13(4), $1-14$.

Su, Y.S., Tsang, E.W., \& Peng, M.W. (2009). How do internal capabilities and external partnerships affect innovativeness? Asia Pacific Journal of Management, 26(2), 309-331. https://doi.org/10.1007/s10490-008-9114-3

Sveiby, K.E., \& Simons, R. (2002). Collaborative climate and effectiveness of knowledge work-an empirical study. Journal of Knowledge Management, 6(5), 420-433. https://doi.org/10.1108/13673270210450388

Tidd, J., Bessant, J., \& Pavitt, K. (2006). Management de l'innovation: Intégration du changement technologique, commercial et organisationnel. De Boeck Supérieur.

Tschannen-Moran, M. (2001). Collaboration and the need fortrust. Journal of Educational Administration, 39(4), 308-331. https://doi.org/10.1108/EUM0000000005493

Tushman, M.L., \& O'Reilly, C.A. (1997). Winning through innovation: A practical guide to leading organizational change and renewal. Harvard Business School Press. Boston, MA.

Vrakking, W.J. (1990). The innovative organization. Long Range Planning, 23(2), 94-102. https://doi.org/10.1016/0024-6301(90)90204-H

Wagner, T. (1998). Change as collaborative inquiry: A'constructivist'methodology for reinventing schools. Phi Delta Kappan, 79(7), 512.

Wang, E.T., \& Wei, H.L. (2007). Interorganizational Governance Value Creation: Coordinating for Information Visibility and Flexibility in Supply Chains. Decision Sciences, 38(4), 647-674. https://doi.org/10.1111/j.1540-5915.2007.00173.x

Wang, S., \& Noe, R.A. (2010). Knowledge sharing: A review and directions for future research. Human Resource Management Review, 20(2), 115-131. https://doi.org/10.1016/j.hrmr.2009.10.001

Wang, Z., \& Wang, N. (2012). Knowledge sharing, innovation and firm performance. Expert Systems With Applications, 39(10), 8899-8908. https://doi.org/10.1016/j.eswa.2012.02.017

Weiss, E.M. (1999). Perceived workplace conditions and first-year teachers' morale, career choice commitment, and planned retention: A secondary analysis. Teaching and Teacher Education, 15(8), 861-879. https://doi.org/10.1016/S0742-051X(99)00040-2

Whitener, E.M., Brodt, S.E., Korsgaard, M.A., \& Werner, J.M. (1998). Managers as initiators of trust: An exchange relationship framework for understanding managerial trustworthy behavior. Academy of Management Review, 23(3), 513-530. https://doi.org/10.5465/amr.1998.926624

Wu, L.Y. (2010). Applicability of the resource-based and dynamic-capability views under environmental volatility. Journal of Business Research, 63(1), 27-31. https://doi.org/10.1016/j.jbusres.2009.01.007

Xiaoming, C., \& Junchen, H. (2012). A literature review on organization culture and corporate performance. International Journal of Business Administration, 3(2), 28.

Yang, Z., Nguyen, V.T., \& Le, P.B. (2018). Knowledge sharing serves as a mediator between collaborative culture and innovation capability: an empirical research. Journal of Business \& Industrial Marketing, 33(7), 958-969. https://doi.org/10.1108/JBIM-10-2017-0245 


\section{Appendix A: Collaborative culture}

$\mathrm{CC} 1$. The company considers changes to be natural and necessary.

$\mathrm{CC} 2$. The company considers individuals as an asset and tries to appreciate them continuously.

CC3. Individuals who experiment and take reasonable risks are well-considered even if they should be mistaken.

CC4. The preservation of different points of view is encouraged.

CC5. Everybody's opinions and contributions are respected.

CC6. Problems are discussed openly, to avoid finding culprits.

CC7. Collaboration and co-operation among the different duties and departments are encouraged.

CC8. All team members are aware of instructor expectations

\section{Appendix B: Innovation capability}

IC1. Our company frequently tries out new ideas

IC2. Our company seeks new ways of doing things

IC3. Our company is creative in its operating methods

IC4. Our company is frequently the first to market new products and services

IC5. Innovation is perceived as too risky in our company and is resisted (reversed coded)

IC6. Our new product introduction has increased during the last five years

\section{Appendix C: Competitive advantage}

CA1. Whether the firm has the competitive advantage of low-cost compared to other competitors.

CA2. Whether the firm has better managerial capability than other competitors.

CA3. Whether the firm's profitability is better than other competitors.

CA4. Whether the firm is the first mover in some important fields and occupies the important position. 